ROCZNIKI HUMANISTYCZNE

Tom LXVIII, zeszyt $11-2020$

DOI: $\mathrm{https://doi.org/10.18290/rh206811-10}$

LEONOR MARÍA MARTÍNEZ SERRANO

\title{
THE MULTITUDINOUS SPARSENESS OF SPACE IN HARRY THURSTON'S BROKEN VESSEL
}

\begin{abstract}
A b s t r a c t. In January and February 2000, Canadian poet-naturalist Harry Thurston (b. 1950) spent 35 days in the Sahara with a team of archaeologists conducting research at the Egyptian oasis of Dakhleh in the Western Desert. Confronted with the vastness of a territory at once foreign and familiar, he decided to respond to the experience of living in the desert with poems of haiku-like brevity he would write each day he spent on camp. The fruit of this spiritual experience was Broken Vessel (2007), a book that seeks to capture the mystery of the desert, a space that has held a century-long fascination for the human imagination. Following Tuan's dichotomy of space vs. place, Bennett's notion of vibrant matter, and ecocritical concepts concerning ecopoetry as place-making, this article examines Thurston's insights into the more-than-human world embodied by the desert, based on his firsthand observations and his imaginings of the known and revealed history of the Sahara.
\end{abstract}

Keywords: Canadian poetry; Harry Thurston; ecopoetry; more-than-human; trans-corporeality; space; place; desert.

\section{A POET-NATURALIST IN AWE WITH THE MORE-THAN-HUMAN WORLD}

Born in 1950 in Yarmouth, Nova Scotia, where he grew up on the family farm, the Canadian poet-naturalist Harry Thurston lives on the banks of the Tidnish River in Cumberland County. He holds a degree in Biology from Acadia University, where he was awarded an honorary Doctorate of Literature in 2013. Ever since 1977, he has worked as a full-time freelance journalist, poet, and editor. He has published several collections of poetry, including Barefaced Stone (1980), Clouds Flying Before the Eye (1985), If Men Lived On Earth (2000), A Ship Portrait (2005), Broken Vessel: Thirty-five Days in the

LeOnor María Martínez Serrano, PhD, University of Córdoba, Department of English and German Philology; address for correspondence: Faculty of Arts and Humanities, Plaza Cardenal Salazar, 3, 14003, Córdoba, Spain; e-mail: 152masel@uco.es; ORCID: https://orcid.org/0000-0002-5114-9513. 
Desert (2007), Animals of My Own Kind. New \& Selected Poems (2009), The Deer Yard (2013, with Allan Cooper), and Keeping Watch at the End of the World (2015). His poetry has been widely anthologised and has appeared in prestigious Canadian journals like The Antigonish Review, The Canadian Forum, The Dalhousie Review, The Fiddlehead, First Encounter, Grain, Pottersfield Portfolio, Poetry Toronto and PRISM International. Among his nonfiction works are Atlantic Outposts (1990), Tidal Life: A Natural History of the Bay of Fundy (1990), Against Darkness and Storm: Lighthouses of the Northeast (1993), Dawning of the Dinosaurs (1994), The Nature of Shorebirds, Nomads of the Wetlands (1996), The Nature of Hummingbirds (1999), The Sea Among the Rocks: Travels in Atlantic Canada (2002), Island of the Blessed: The Secrets of Egypt's Everlasting Oasis (2003), A Place Between the Tides: A Naturalist's Reflections on the Salt Marsh (2004), The Sea's Voice: An Anthology of Atlantic Canadian Nature Writing (2005, editor), Silver Ghost: An Homage to the Atlantic Salmon Rivers of Eastern Canada (2008), and The Atlantic Coast: A Natural History (2011). All of these testify to the vastness and curiosity of his ecological mind. As a naturalist, he has contributed numerous articles to over thirty North-American magazines specialising in environmental issues and natural history such as Atlantic Insight, Audubon, Books in Canada, Canadian Art, Equinox, Harrowsmith, National Geographic, Quill \& Quire, Reader's Digest, Rotunda and Yankee Homes. His poetry and nonfiction have been awarded prestigious prizes such as the Sigurd Olson Nature Writing Award, the Lane Anderson Award, and the Evelyn Richardson Literary Award.

A poet-naturalist in the Thoreauvian tradition, Thurston constantly reminds us of how important it is to be fully present in the midst of our own brief lives and to be sensitive to the more-than-human world around us. Of If Men Lived on Earth (2000), the Canadian poet and critic George Elliott Clarke said in a review published by The Halifax Sunday Herald: "The lines are clear, thought-through, elemental, irrefutable. They transform history, economics, and ecology into experienced truth.... Thurston is a marvellous poet." The same can be aptly said of Broken Vessel, a book of poems that chronicles his 35-day stay in the Sahara, where he experiences firsthand the sparseness of a landscape that, far from being empty, is teeming with life and full of signs and voices coming from afar. As an environmental journalist contributing articles to some of North-America's leading magazines, Thurston has travelled widely. The poems gathered in Broken Vessel sprang from his travels, in 2000, to the Egyptian oasis of Dakhleh in the Western Desert, which also led to the publication of the nonfiction work Island of the Blessed: The Secrets of Egypt's Everlasting Oasis (titled Secrets of the Sands: The Revelations of 
Egypt's Everlasting Oasis in the 2004 US edition) to wide critical acclaim in 2003. On the dustjacket flap of the US edition we read:

Amid a sea of sand, in a part of Egypt so parched that decades pass between rainstorms, a green island may contain the whole of human history. It is called Dakhleh, the "everlasting oasis," and it holds a rich trove of archaeological clues.... Over the course of a thirty-year dig, [an international team of archeologists] has discovered a perfect Old Kingdom town, with buildings ranging from palaces to common bakeries; the oldest monumental architecture in Egypt, even older than the pyramids; an archive of 10,000 papyri; huge caches of mummies, some still covered in ancient foil; an entire Roman city ... and the world's two oldest books, their pages of thin wood still bound together with age-old string. Perhaps most impressive of all is that these discoveries occurred in a single, magical place where it is possible to trace human habitation back more than 400,000 years - before the advent of modern Homo sapiens.

Given the cultural and natural wealth associated with the place, it is no wonder that the Dakhleh Oasis, the site of the longest uninterrupted human habitation on Earth, should have exuded fascination on archaeologists, palaeontologists and other scientists for so long. Thurston is not immune to the overwhelming fascination the place exerts upon the human imagination. His response to the place materialised first as a work of nonfiction, where he gives a rich account of the excavation research project at the Dakhleh Oasis and seeks to unearth "the Sahara's vast archive of sands" (Island of the Blessed 8), and as a book of poems eventually. Following the team of archaeologists in their daily activities and sharing life camp with them, Thurston made up his mind to write a poem of haiku-like brevity and intensity each day he spent on the site. Most of his poems capture the sparseness, vastness, and beauty of the desert landscape, while some others evoke episodes of the known history of the Sahara or the history revealed by archaeological findings and fragments rescued from the past. The poet's own musings are thus intermingled with his observations of the Sahara, his knowledge of the received history and the newly discovered evidence that hints at a lusher, greener environment where ancient peoples dwelled long ago, whilst shedding light on the innermost recesses of the place.

Broken Vessel consists of a total of 35 poems, which resemble the tiny tesserae of a gigantic and yet incomplete mosaic. As the poet makes clear in the brief but informative foreword to his slim collection, the poems were written in January and February of 2000, one for each day that the poet spent in Egypt's Western Desert, or to be more accurate, at the Dakhleh Oasis, "located 
270 kilometres west of the Nile and 600 kilometres southwest of Cairo" (Broken Vessel np). According to the author:

In January 2000, I travelled to the Egyptian oasis of Dakhleh - the "Inner" oasis - in the Western Desert, 600 kilometres southwest of Cairo as the crow flies. I was there to research a non-fiction book on the history of this so-called "everlasting oasis," where, archaeologists have shown, people have lived continuously for nearly half a million years. Travel often inspires me to write new poetry, and the clarity of the desert environment (which arises, I think, from its starkness and immensity) seemed to beg for a response in verse as well as prose. I decided to write a single poem at the end of each day's exploration of the oasis and the surrounding desert. ("Note")

Thus, the poems in Broken Vessel were originally prompted by three main sources: "my firsthand observations of the desert environment and the things living in it; the Western Desert's known history; and my daily discovery of its revealed history, the last through the careful work of my [archaeologist] companions" (Broken Vessel). His poetic agenda was simple and straightforward from the outset, as his plan was "to apprehend what I could in this, to me, foreign environment, then to respond extemporaneously in poetry, and to revise minimally at some later date" (Broken Vessel). Significantly enough, 25 out of the 35 poems (six of which dwell on animals) stem from Thurston's sensuous encounter with the vibrant materiality of the desert, six poems deal with the known history of the Sahara, and the remaining four poems explore the revealed history of the place in the light of the archaeologists' findings on the site. Confronted with the sparseness and vastness of the desert, Thurston was aware that it was a place alive with stories and voices from the past. He explains: "In undertaking these poems, I was conscious of the belief in Western civilization that the desert is a place of revelation, where, through removal from society-at-large, one might hope to achieve a greater clarity of purpose" (Broken Vessel). This belief finds an echo in the deceptive simplicity and nakedness of Thurston's 35 poems. Together, they form an accomplished meditation on the Sahara desert, a landscape that is a constellation of sand, sky and light, wind and scorching heat, fossils, bones and footprints, home to the scarab beetle leaving signs on the sands. But it is also a place rich in myths, in presences and historical figures from ancient civilisations ranging from Cleopatra and Julius Caesar to the anchorites leading monastic lives of deprivation away from human commerce. The poet's attention thus shifts from the real to the imaginary, mythical or visionary, from the weather and sandstorms to desert animals, gods and ancient soldiers, bones and archaeological findings, oases, and journeying. As a whole, Broken Vessel conveys a profound 
sense of impermanence and mortality, of the fragility of the more-than-human world, while capturing the sparseness and nakedness of the desert landscape through eco-poems that are sensitive to the subtle nuances implicit in space and in place. Yet Broken Vessel also speaks to a kind of resilience, a longevity that thrives in the cycles of impermanence and mortality, as evinced by some of the poems in the collection.

Thurston is an ecopoet sensitive to the reciprocity or interdependence of the human and the nonhuman. According to Bristow, 'more-than-human' is "a general term reminding us that the non-human world (on which humans are absolutely dependent) has agencies of its own" (126) and is an interwoven mesh of bodily natures. It offers an alternative to the Cartesian res cogitans (mind, spirit) vs. res extensa (body, matter) dualism deeply entrenched in Western thought, which has substantiated human exceptionalism and domination over the earth on the assumption that Homo sapiens is on the summit of creation. As "a focal alternative to the prevailing human/non-human perspective in bio (life) and geo (earth)," Bristow maintains, 'more-than-human' "celebrates the 'livingness' of the world" (6), counters "a dualist sense of nature as something external to humans" (125), and gestures towards a view of human beings as being part of the flesh of the earth. In this regard, Thurston is well aware that the biosphere is a vast network of connections where the perceiving self is deeply immersed. In an interview with Lisa Szabo-Jones, the poet admits that "writing has to proceed from the senses" (87) and that his desire "to become a poet was, in a sense, a search to express [his] wonder about the natural world" (87). David Abram's book The Spell of the Sensuous (1996) was a revelation to him when he read it for the first time, as the ecophilosopher traces "how our bodily response, which is reciprocal with the environment, is a source of language" (Szabo-Jones, "Interview" 87). With Abram, Thurston believes that language is a kind of permeable "membrane between the human and the non-human world" (Szabo-Jones, "Interview" 88) and so his poems and nonfiction are his way of responding to the awe-inspiring complexity of reality. Convinced of the value of observation to unearth "the patterns ... that give rhythm to our lives," the poet embraces "almost a monkish dedication to seeing what you can see" (Szabo-Jones, "Interview" 88), to really apprehending what is close at hand. Perception is first and foremost the most immediate evidence of our bodily participation in reality, since "sensory perception is the environmental engagement of every organism at its most basic" (Sullivan 81). In other words, his ecological phenomenological approach to the physical world-to oikos as the home of life-is ultimately one based on paying attention and on 
the sensuous immersion of the embodied self in a more-than-human world. Because we are a part of - not apart from - the breathing world, Thurston argues that "our responsibility lies in trying to make what sense we can of it, including how we are placed within the bigger picture" (Szabo-Jones, "Interview" 92). In Broken Vessel, the desert Thurston is confronted with is perceived as being not external to humanity, but ultimately co-extensive with it. In what follows, this article examines Thurston's lyrical and ecological experience of space and place, by looking closely at his poems through three analytical categories: his firsthand observations, the known history and the revealed history of the Sahara. The acts of perception and imagining in the poet's mind are inextricably linked to each other, though.

\section{FIRSTHAND OBSERVATIONS OF THE DESERT}

Broken Vessel shows Thurston depicting a landscape that resists clarity and epistemological conquest on the part of the human mind, whilst capturing a wide "range of the nonhuman powers circulating around and within human bodies" (Bennett ix). In her homonymous book, Bennett posits the notion of vibrant matter, by which she means that matter is not passive or simply acted upon, but has the capacity to play a decisive role in the fabric and events of the universe. As Joni Adamson puts it, agency means that "non-human natures (sentient beings, animals, and matter in its organic forms) are considered to be agentic in the sense that all have powerful effects and in a way interact with their environment in differing degrees" (267). As pointed out above, Thurston determined to compose a series of short, lyrical poems during his 35-day residency with a team of archaeologists at the Dakhleh (or innermost) Oasis in Egypt in January-February 2000. As Szabo-Jones suggests, Thurston "layers his poems with a temporal attunement to ecology and environment, Western Desert history, and archaeological findings" ("Dwelling" 196). In fact, 25 poems out of the 35 making up the collection arise from the poet's encounter with the desert - from his sensory observations of a landscape that defies all expectations or preconceived ideas. A landscape lush in negation, the desert as negative space: this is what Thurston's poetic self experiences and records in a series of snapshots that seek to capture and render the singularity of the Sahara desert as accurately as possible. Thus, in poem after poem, he does not give up on his attempt at grasping the unknowable implicit in the vastness of the desert 
qua mystery and unfamiliar territory. As the collection unfolds, effective structuring dichotomies become discernible: darkness vs. light/clarity, vastness of space vs. sense of closeness, lack of water vs. oasis, past vs. present.

The kaleidoscopic, shifting nature of the desert becomes apparent from the very outset. At night, looking at the beautiful desert sky, Thurston observes a myriad stars "piercing the sky/with a promise/of clarity" (Broken Vessel 1). But the promise of (epistemological) clarity appears to remain unfulfilled by the end of the collection, as the poet relentlessly essays innumerable variations on the same theme, seeking to apprehend the nature of the desert, one of those overwhelming spaces tessellating the surface of the Earth that resists total interpretation on the part of the inquisitive gaze of Homo sapiens. What Thurston finds instead is a world of murmuring voices, full of signs, footprints and fossils that speak in more-than-human tongues. The desert is soon conceptualised as being "a broken vessel," with "its sherds/scattered/on the thirsty ground" (Broken Vessel 2), peppered with fragments from beyond time that betray the unfathomable nature of this space when confronted by the naked human eye. The sherds are an apt metaphor for the poems in Broken Vessel, "poetic shards that leave open to speculation the missing pieces, the cracks, and precariousness of desert life" (Szabo-Jones, "Dwelling" 196), animating the shifting borders between the living and the non-living, the present and the past. And yet a whole out of fragments appears to take form as the book unfolds into an astounded flower, like the very rose of the desert "blossoming/out of barrenness" (Broken Vessel 3), which is indicative of resilience, namely the persistence of life amid an overtly hostile environment. As Alaimo observes in "Bring Your Shovel!" (2014), "when considered from a more-than-human perspective," and not from an anthropocentric vantage point, resilience "reminds us of the worldly agencies, energies, and transformations that can generate unexpected vital beings, life forms, and relations." What is more, in the face of the anthropogenic destruction of the biosphere, Alaimo calls for the urgent need to take action to ensure "the resilience of ecosystems, the survival of species, the just distribution of health, wealth and opportunity," for social justice is ultimately inseparable from environmental justice.

The hostility of the desert as a space where humans struggle to find their way around is a recurrent motif in Thurston's collection. Navigating space where there are only shifting signs and no compass other than the night sky, "the quarter moon/and its companion star/shining in the black chart" (Broken Vessel 6), might lead to a very shattering experience for humans, surrounded by a vast sea of sands with "the migrating sun/glancing off/endless crests" (Broken Vessel 7). The experience of humans getting lost in the desert is thus 
conveyed with powerful lyricism, in terms reminiscent of Eliot's death by water in The Waste Land (1922): people might end up drifting for long days and weeks, looking desperately for an oasis, and eventually they may die of thirst "like the sailor/maddened by water/all around" (Broken Vessel 7). If anything, the desert is a place of negation: a place where the lack of waterthe elementary source that makes life possible - is a real menace to humans' physical integrity and continuing existence. Thurston reminds readers of the ancient lush and wetness that pervaded the Sahara eons of time ago. Hard to believe as it may now seem to be, "the ghost of a lake" (Broken Vessel 8) speaks of a time when water was ubiquitous, even if now people crossing the desert may "see water everywhere" (Broken Vessel 9) and start digging deeper and deeper only to find a well that fills with more sand or simply despair. Now the desert traveller is "cursed by the dry cataract/of salt, a stinging/white blindness" (Broken Vessel 10), the result of scorching heat and an unbearably dry weather, with no trace of moisture to be felt anywhere. On day 32 of his stay in the desert, upon encountering "camel bones" bleaching in the sun, "bitter/reminders of the desert way" (Broken Vessel 32), Thurston meditates on the sheer vastness of the desert and on the "ceaseless journeying" of the old days. The camel bones themselves are an example of what Bennett calls "vibrant matter," for they have an agency of their own and are part of a larger assemblage in the ecosystem of the desert.

During his stay in the desert in the company of archaeologists doing field work, the poet felt at home. As Thurston himself explains, far from being deprived, he lived "in a Spartan but comfortable mud-brick house and was blessed with good company, food and drink" (Broken Vessel np). However, the desert is an ocean of endless sand dunes, and sometimes nature takes revenge in the form of a sand storm, "an invisible invader" (Broken Vessel 18) that conquers everything that comes in its way, from homes to wood and accounts kept by the team of archaeologists working at the Dakhleh Oasis, which cannot be salvaged easily, given the fury of the sands, "while the sands rose/to the rooftop/of our beloved home" (Broken Vessel 18). Other times, the desert seems to take revenge in the form of the khamsim (Fifty Days' Wind), conquering the sky with "hordes of dust" and leaving "your tongue thickened with earth" (Broken Vessel 33). This is expressive of the wind as vibrant matter or agentive force, proclaiming its dominion over the desert sands, moulding the landscape at its free will as if it were a powerful, inspired sculptor. What is more, the desert also "claims the body," and 
in time the skin smells of it -

incendiary,

about to burst into flame

leaving a residue

of dark passion,

blistering light.

(Broken Vessel 28)

These lines speak to an underlying eco-eroticism that pulses through Thurston's Broken Vessel and surfaces here and there in other poems in the collection. Sensuously immersed in the more-than-human world, the poetic persona's body resonates with the body of the desert. By positing the notion of 'transcorporeality,' Alaimo maintains that the human body is a porous entity open to the flow of substances in a world of material beings. It follows that "the corporeal substance of the human is ultimately inseparable from 'the environment" ("Trans-corporeal" 238). If there is a permeable membrane between human bodies and the more-than-human world of which they are a part, then it is hard, if not impossible, to pinpoint clear-cut boundaries between earthly entities. This betrays the porosity of our bodies and the permeability "between our flesh and the flesh of the world" (Tuana 188).

At any rate, there are two elementary ingredients that are central to the configuration of the desert qua space, namely light and silence. The desert is not only a landscape marked by an acute sense of lack (i.e., lack of water, lack of signposts helping travellers to find their way around), but also by a deep sense of excess - of sunlight and silence. Desert cities are built the way they are built to ensure protective (and yet oppressive) shade for its dwellers, since if they were to escape "this veiled precinct,/the light might sear,/the gates swing shut forever" (Broken Vessel 30). To city dwellers from other parts of the world, silence is possibly the most noticeable element that is part and parcel of the desert. As the poetic voice observes, silence in the desert is punctuated by the sound made by "broken pots underfoot" (Broken Vessel 31). In this respect, Thurston writes a jewel-like lyric of utter precision to evoke how silence is pervasive in the desert and sounds "like the decrepit patter/of broken pots/underfoot" (Broken Vessel 31). In a world of sand dunes and extreme temperatures, the marriage of sound and silence is the music of a landscape that speaks in a myriad of languages.

There is in Broken Vessel a sense of a fine mind taking in the world and giving back to us a vivid picture of a mysterious space like the Sahara desert. Thus, in much the same way Thurston's ear is sensitive to the sonic texture of 
the desert, his eye is also alert to its hues and colours: "red ochre for passion," "yellow ochre for peace," "white for the salt pillar" and "porphyry for the old gold/of the desert" (Broken Vessel 22), writes the poet. In evocative parallelistic lines, Thurston juxtaposes the real desert his eyes are witnessing firsthand with a visionary, mythical desert from the past populated by gods and goddesses, gladiators, anchorites and sects leading an ascetic life of deprivation in the desert. At that point, an outsider's reflection on the immensity of the place becomes a series of poems that render the desert into a vortex of presences past and present, which are "translations, albeit mystifying and compelling reflections of the poet's relation to place and time" (Szabo-Jones, "Dwelling" 196). What connects all the poems are Thurston's powers of insight and the implied relations between his sparkling revelations concerning the surface and deep nature of the desert as a space replete with resonances and murmurings. In this respect, the boundary separating the living and the dead becomes ever blurrier and "What man has buried/the wind resurrects. What time has separated/the wind brings together" (Broken Vessel 34). As Szabo-Jones observes, "[r]emnants of civilizations, architecture, and flora and fauna both dissolve and refortify the divide between nature and human in a seemingly endless interchange between living and non-living, between human activity and environmental forces" ("Dwelling" 196).

At least three poems in Thurston's collection evoke the redeeming power of the life-giving element that water is. On day 29 , the poet meditates on the power of rain to "return/us to our senses" (Broken Vessel 29) and on the "smell of wet earth,/the taste of wet skin," which he perceives as an "antidote to the dry/dissertations/of the desert" (Broken Vessel 29). Even more accomplished are the two poems devoted to recreating the paradise that an oasis embodies amid the barrenness of the desert. On day 25, Thurston writes:

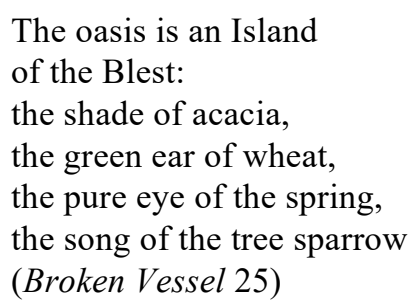

Amidst a hostile natural world, the oasis represents the promise of fertility, conviviality and greenness. An "Island of the Blest" amid the waste land of the desert - the oasis Thurston gets to have an intimate knowledge of-is 
a discrete sequence of elements that betrays the abundance of the green world: the shade provided by generous trees like the acacia, the promise of food as represented by wheat, the life-giving properties of the water emanating from the spring, and the music of what-is as embodied by the sparrow. Against this idyllic natural backdrop are the silhouettes of women tilling the land, so that it will yield the nutriment needed by humans. At the interplay between the human and the nonhuman, Thurston captures "the other-than-human presences that surround the oasis" and fills the desert's silence with "the songs and traces of living creatures" (Szabo-Jones, "Dwelling" 196), including the song of the zerzura, the little bird or sparrow dwelling in the oasis. Last but not least, on day 26 of his stay in the desert, Thurston muses on the olive, lemon and orange trees that make up the garden and oasis where the poet and his archaeologist companions are staying, and on the "doves fanning their wings/against the dusty fronds,/murmuring their prayers" (Broken Vessel 26) as the sun sets on the horizon. By hinting at the exuberance of such biodiversity, seemingly at odds with the prevailing barrenness of the vast expanses of land surrounding the oasis, Thurston underscores resilience - the persistence of varied life forms in the desert.

There is in Broken Vessel a significant cluster of six poems that offer luminous glimpses of the desert wildlife. As a consummate poet-naturalist, Thurston has a fine ear and a fine eye for the wild animals populating the desert, too. Along with the sparrows, egrets and doves of the oasis evoked in poems 25, 26 and 29, scarab beetles, snakes, Dorcas gazelles, hyenas, hawks, and larks all figure prominently as the main focus - and as the native dwellers of the desert-in six other poems in the collection. The poem written on day 11 is particularly relevant in this respect: "The scarab beetle/skitters across hot sands,/signing its hieroglyphic track" (Broken Vessel 11). The tracks it leaves on the sands may seem of no relevance at all, and yet, by writing on the sands, it "brings the world/into being" (Broken Vessel 11), confesses the poet. Semiosis is an aspect of reality and meaning is not a human prerogative, or so seem to suggest these lines, where Thurston embraces biocentrism instead of anthropocentrism. It is bios (life), not homo sapiens, that is the measure of the cosmos. As Aldo Leopold (1970) put it in a classic, A Sand County Almanac, "[a] thing is right when it tends to preserve the integrity, stability, and beauty of the biotic community" (262). In nature there are signatura rerum, signs needing no verbal tradition, for the human eye to decipher and interpret. It is as if the characters used if the characters used by the scarab resembled those of a human alphabet. This is the domain of 
biosemiotics, which seeks to shed light on meaning-making processes on the part of very diverse living forms in the world at large.

Coming across a snake sunning itself on a rock, the poetic voice wonders what the point is in killing it: "what then will you do, now you are/the only living thing in the desert?" (Broken Vessel 15). These words are a powerful reminder that a snake found in the desert is a clear indicator of other undetected, hidden life. Likewise, they are expressive of the wider meditative and life-preserving implications buried in this poetic moment with the texture of revelation. What is at stake here is not just compassion towards the nonhuman, but also a poignant recognition that humans are part of a continuum of life spanning from the sparrow through the snake to the gazelle and the lark. All of them are dwellers of one and the same earth, plain citizens of the biotic community in Leopold's well-known formulation. Heidegger, who set out to think dwelling, claimed in memorable words that "[m]an is not the lord of beings. Man is the shepherd of Being" (245), which is to say that humans are part and parcel of the living mesh of things in a more-than-human world. In the meantime, the Dorcas gazelle leaves "tiny heart-shaped tracks" (Broken Vessel 16), busy with its own writing on the sands, which disappears "into empty/mysteries" (Broken Vessel 16), and the hyena hides in a cave that is a cache full of bones and hair from very diverse preys, "safe from wind and man" (Broken Vessel 17). On day 23, Thurston comes across a hawk, perched on "the wreckage of a ruined church/nearly as old as the Apostles" (Broken Vessel 23). In a hawk's world there is no room for gods or goddesses, unless "that god is a hawk/silhouetted against/the life-giving sun" (Broken Vessel 23). And on the very last day of his sojourn in the desert, Thurston chooses to bring his book to a close with a moving poem on a lark where we read these lines tinged with nostalgia:

\footnotetext{
We need things that cannot be found.

If they do not exist, all the better.

(Broken Vessel 35)
}

The poet is possibly gesturing towards the final unknowability of the world, to the need to embrace humility and uncertainty in the face of reality, and also to human dependency on the nonhuman in a world where we are just a tiny thread in the vast tapestry of existence. In other words, he is thinking like an ecosystem - not like a tourist, a visitor or an outsider, but like someone who finds himself at home. If there are things that do not exist, if might be "all the 
better," because, named or unnamed, if they exist, we might kill them. Humans' compulsion is to conquer and domesticate the nonhuman, to see the world as a commodity or portfolio of resources to be exploited to suit their needs for material comfort. And yet there are things that exist in spite of us. Being and beauty will persist despite relentless change and destruction, or so seems to suggest Thurston.

Following Barad's insight that "[matter] is not little bits of nature, or a blank slate, surface, or site passively awaiting signification" (151), our contention is that Thurston resists with great perspicacity all attempts at anthropomorphisation, while translating the existence of the animal species dwelling in the desert from the world of what-is to the world of what-means, i.e., from the sheer physicality of reality to the realm of language, and back again. The results of this interspecies encounter might as well be interspecies transcreations or a language-mediated transposition from the ecosphere to the page. What is worth emphasising is that Thurston responds to the vibrancy of matter and to the singularity of the desert, a world rich in species other than human, with utmost respect and empathetic resonance. The lesson the poet might ultimately be said to gain is that Homo sapiens is just a part of a world where Alaimo's notion of transcorporeality, i.e., "human corporeality as trans-corporeality, in which the human is always intermeshed with the more-than-human world" (Bodily Natures 2), is simply ubiquitous.

\section{WHAT KNOWN HISTORY TELLS US ABOUT THE DESERT}

In Space and Place: The Perspective of Experience, cultural geographer $\mathrm{Yi}-\mathrm{Fu}$ Tuan draws a distinction between space and place that can prove useful in accounting for what Thurston accomplishes in Broken Vessel. He points out that "space' is more abstract than 'place.' What begins as an undifferentiated space becomes place as we get to know it better and endow it with value" (Tuan 6). Space is inextricably linked to freedom and the power to move, which is an elementary compulsion common to all humans. If space is "that which allows movement, then place is pause; each pause in movement makes it possible for location to be transformed into place" (Tuan 6). Put differently, "enclosed and humanized space is place" (Tuan 54). As a poet-naturalist sensitive to space and to place, Thurston can be considered a place-maker: by writing poems on the more-than-human world, as happens to be the case in Broken Vessel, a dexterous exploration of the desert as a complex space-place, he cultivates Tuanian topophilia, i.e., "the affective bond between people and 
place or setting" (Tuan and Schoff 4). The desert is not just a physical space, but the embodiment or treasure-house of cultural associations that appear to be omnipresent in people's imagination. Broken Vessel shows Thurston writing space and place, fleshing them out in and through words, to make the experience of his confrontation with the sublime sparseness, power and vastness of this unfamiliar landscape communicable to others, whilst gesturing towards the bond uniting the living and the nonliving, the human and the nonhuman, the past and the present, the naturecultures of which humans are just a tiny thread.

To Thurston's poetic sensibility, the archive of the sands of the Sahara is full of the ancestors' voices coming from afar. It is a murmuring place, replete with signs everywhere, for the book of the desert is written in both human and nonhuman characters. The living and the dead intermingle, and echoes from the past coalesce to form a sequence of six poems that are tesserae of the mosaic of History. As a site of narrativity, the vibrant matter of the desert tells many stories about what happened in the past, throughout the centuries. This is an insight gained early in Thurston's stay at Dakhleh. Once a fertile ground, an Eden or Paradise on earth, the Sahara was a place teeming with life, full of water, flora and fauna, "where trees once filled/with birds, ponds cradled/turtle, hippo and catfish" (Broken Vessel 5). It was also home to the splendour of ancient civilisations at a time when "the mingling of lost voices" (Broken Vessel 4) around the fires in the desert was common practice in a Babel-like world, at a time when goddesses were worshipped and "There were mystic animals/flickering into life on rock faces - /before the rains failed to fall" (Broken Vessel 4). This is the historical side to the Sahara that Thurston imagines and visualises when confronted with foreign yet familiar territory. It remains alien terrain, but it is also familiar in the sense that the poet is able to grasp layer upon layer of the known history an educated person may have formed in their mind about the place in question. The Sahara reveals itself to be a place steeped in history, with deep roots firmly planted in the past, and so everywhere the poet's gaze turns to, it cannot but unveil hidden presences behind the surface of the landscape. The names of Cleopatra, Caesar and the anchorites are all inextricably linked to this desert where the living and the dead appear to coexist in a timeless realm where ticking clocks are not in working order any more. For instance, on day 13, Thurston takes a moment to dwell on Cleopatra's death, on mortality and on human vanity. The Egyptian queen's history is well known, but the poet evokes it with just a few brush strokes as it were, with great linguistic economy. He muses on Cleopatra's 
breasts, which inspired not only "treachery, knives/in the back," but also "tectonic/acts that shook/faraway Rome" (Broken Vessel 13). After so many centuries have elapsed, it does not matter much whether she clasped one or two asps to one or two of her breasts. The point is that "Empires fall./Does it matter if one's death/is imperial or common?" (Broken Vessel 13). Death remains the ultimate, inevitable frontier and the universal equaliser for all humans. Life is so short a breath that we had better not waste our precious time, since once the asp has bitten its victim, "there is only time/to smoke one cigarette" (Broken Vessel 13). Julius Caesar is another such imperial name associated with the Sahara. The territorial imperative pushed Caesar to expand the boundaries of the Roman Empire further and further into remote foreign lands. Believing he would succeed in pushing back "the desert borders/like legions crossing/a battleline" (Broken Vessel 21), his "imperial ambitions" were finally mocked by "the infinite horizons" (Broken Vessel 21) of the shifting desert. This is a form of hubris: the unappeasable desire to conquer is drowned by the emperor's compulsion to expand his power over other peoples and lands. All is vanity in the end; dreams of grandeur are shattered and ambitions collapse.

In sharp contrast to the poems devoted to the imperial ambitions of Cleopatra and Caesar stand poems 24 and 27, which evoke exactly the opposite: the ascetic lives of deprivation, renunciation and self-abnegation of the Desert Fathers and anchorites who chose to live in solitude and communion with the natural world. In fact, the desert is not only the setting of imperial ambitions like the ones that possessed the Egyptian queen and the Roman emperor, but also a place for spiritual self-renewal and soul purification. Aware of this dimension to the desert, in the prologue to his collection Thurston writes:

The tradition of going to the desert is an old one. The Essenes were a pre-Christian sect who lived an ascetic life in the desert bordering the Dead Sea. Jesus went into the desert after his baptism for "forty days and forty nights," during which he rejected the temptations of Satan and affirmed his earthly mission. In the third century, the Desert Fathers of Egypt (and anchorites) followed Jesus's example by living monastic lives in the desert marked by material deprivation. Dakhleh has a cave where one of these holy men supposedly sought a richer spirituality through contemplation. (Broken Vessel)

Poem 27 shows one of those holy men "draped in green," which is a sacred colour standing for "green of the oasis, / of life and paradise" (Broken Vessel 27). Amidst a barren landscape of infertility, green represents plenitude, abundance, and the richness implicit in the life of renunciation lived by these holy men. Finally, in poem 24, the moving voice of one of those Desert Fathers 
speaks in the first person singular about his own exile: he is "far from Alexandria,/the fertile delta/and my fellows believers" (Broken Vessel 24), with the pagans being his "only salvation" (Broken Vessel 24) now.

\section{ARCHEOLOGY SPEAKS: HISTORY REVEALED}

Four poems in Broken Vessel explore history revealed, namely the lessons gained about the past through the archaeological findings accomplished by the team of archaeologists in whose company Thurston spent 35 days in the Western Desert. Thus, poem 12 is a powerful evocation of a soldier from the past on duty, keeping watch with a spear in his hand, killing time doing different kinds of things to overcome boredom: "he carves his hand,/his foot, in the rock,/ signatures" (Broken Vessel 12). Like the Dorcas gazelle and the scarab beetle, he also leaves tracks and signs for subsequent generations to decipher and interpret. His writing speaks of "the birds and animals/he has killed" and of "the women/he wishes to love" (Broken Vessel 12). For the archaeologists reading the desert, interpreting these signs, the message in a bottle is crystal clear: humans' dreams and preoccupations remain the same despite the passage of time. The hunger for love and acceptance, the need for emotional warmth and the sense that one fits in in a community are universal compulsions inherent in humankind.

On day 14, Thurston comes across the reality of grave robbers in the desert, looking for gold in ancient, regal tombs. What they and archaeologists find in the tombs, to the deepest of their disappointments, is just "unadorned bones" and "humble linens winding the dead/as poor in life as themselves" (Broken Vessel 14). Archaeologists have the power to make bones confess their story, but ultimately bones remain a moving reminder of humans' fragility and mortality. Bones have an agency of their own: despite their bareness and unadorned nakedness, they are vessels of meaning and speak of shattered dreams. Bones are the focus of the poet's attention once again on day 19, when an image of a lost city is reconstructed thanks to archaeological findings and painstaking patience: "the grand house with its domes,/pendentives and frescoes" and "the stone temples of the pagan gods, /the fort and its vanished legions" (Broken Vessel 19) are unearthed from oblivion. Not without nostalgia, the poet acknowledges that the bones of the dead whitening in the sun are a potent reminder of the relentless agentic powers of the desert sand. The stones remain intact, the bones that resemble the stones have also survived the inexorable 
passage of time, but humans are gone and human presence can only be sensed obliquely, in indirect ways. Finally, poem 20 is another powerful lyric that recreates the thrilling moment when a new tomb is discovered. A figure of high station speaks in the first person singular and the exhortations written on the stone in Greek, the lingua franca of the time, are fragmentary. Only a handful of luminous words - "the blood, sacred feast, guarding" - have been preserved, but they remain "indecipherable, the syntax lost" (Broken Vessel 20), just like the city over which this governor, overseer or chief accountant exerted his dominion long ago. Not a single stone of this ancient city stands now; time and the Sahara have conquered everything, inevitably, in the end.

In conclusion, Broken Vessel remains a powerful record of Thurston's sensibility, a fine mind responding to the singularity of the desert environment and to the agency of its creatures and things with great intellectual alertness and ecological awareness. The poet's comprehensive mapping of the desert in Broken Vessel is expressive of what Bristow terms "earth scripts - made by humans who are part of the earth - ... inherently self-conscious writerly descriptions of our spaces fleshed out by the more-than-human world" (8). $\mathrm{He}$ encourages us to see "the human as one part of the more-than-human world, which is to think of us not within the world but of the World" (2), a position that counteracts human exceptionalism and "shifts focus from the significance of human species to transcorporeality and personhood" (2). In this regard, in The Spell of the Sensuous and Becoming Animal, Abram has tirelessly emphasised that humans are just embodied minds sensuously immersed in the living fabric of the earth. In our sensitive and intellectual confrontation with the world, language plays a crucial role as a mediating membrane and air turns out to be the dwelling of what he memorably terms a "Commonwealth of Breath" (Afterword 313) that brings together all living forms in the biosphere, which is the home life has built for itself. Following Abram's insights into the more-than-human world, Thurston embraces an ecological, phenomenological approach to the desert as a place of vibrant matter and agentic bodies that resists interpretation. The self-imposed discipline the poet chooses for himself is none other than close observation of what is close at hand and, as a result, Broken Vessel reads as a diary of his 35-day sojourn in the Sahara. The 35 poems shed light on the manifold details of a place that reveals itself to be a site of narrativity - a place that is replete with signs, stories and other-than-human tongues. Even in a hostile landscape like the Sahara desert, life thrives in a variety of forms, and vitality is discernible in animate and inanimate forces alike. Sensuously immersed in this unfamiliar place, Thurston comes to the realisation 
that the Spartan discipline of perception yields abundant fruits and the all-important lesson that Homo sapiens is part of - not apart from - a many-voiced world populated by creatures that share the same semiotic-material substratum.

\section{WORKS CITED}

Abram, David. "Afterword: The Commonwealth of Breath.” Material Ecocriticism, edited by Serenella Iovino and Serpil Oppermann, Indiana UP, 2014, pp. 301-14.

Abram, David. Becoming Animal. An Earthly Cosmology. Vintage Books, 2010.

Abram, David. The Spell of the Sensuous. Perception and Language in a More-Than-Human World. Vintage Books, 1996.

Adamson, Joni. "Source of Life. Avatar, Amazonia, and an Ecology of Selves." Material Ecocriticism, edited by Serenella Iovino and Serpil Oppermann, Indiana UP, 2014, pp. 253-68.

Alaimo, Stacy. "Bring Your Shovel!” Resilience: A Journal of the Environmental Humanities, vol. 1, no. 1, January 2014.

Alaimo, Stacy. Bodily Natures. Science, Environment, and the Material Self. Indiana UP, 2010.

Alaimo, Stacy. "Trans-corporeal Feminisms and the Ethical Space of Nature." Material Feminisms, edited by Stacy Alaimo and Susan Hekman, Indiana UP, 2008, pp. 237-64.

Barad, Karen. Meeting the Universe Halfway. Quantum Physics and the Entanglement of Matter and Meaning. Duke UP, 2007.

Bennett, Jane. Vibrant Matter. A Political Ecology of Things. Duke UP, 2010.

Bristow, Tom. The Anthropocene Lyric: An Affective Geography of Poetry, Person, Place. Palgrave Pivot, 2015.

Clarke, George Elliott. “Thurston's Offering Glorious.” The Sunday Halifax Herald, 30 April 2000.

Heidegger, Martin. Basic Writings, edited by David Farrell Krell, Routledge, 1993.

Leopold, Aldo. A Sand County Almanac: With Essays on Conservation from Round River. 1949. Ballantine, 1970.

Thurston, Harry. Broken Vessel. Thirty-five Days in the Desert. Gaspereau Press, 2007.

Thurston, Harry. "Note on Broken Vessel." Gaspereau Press, www.gaspereau.com/bookInfo.php ?AID=0\&AISBN=9781554470341. Accessed 5 Jan. 2020.

Thurston, Harry. Secrets of the Sands: The Revelations of Egypt's Everlasting Oasis. Arcade Publishing, 2004.

Thurston, Harry. Island of the Blessed: The Secrets of Egypt's Everlasting Oasis. Doubleday, 2003.

Sullivan, Heather I. "The Ecology of Colors. Goethe's Materialist Optics and Ecological Posthumanism." Material Ecocriticism, edited by Serenella Iovino and Serpil Opperman, Indiana UP, 2014, pp. 80-94.

Szabo-Jones, Lisa. "Interview of Harry Thurston." The Goose, vol. 9, Summer 2011, pp. 80-93, www.alecc.ca/uploads/TheGoose_9_Summer_2011.pdf. Accessed 5 Jan. 2020.

Szabo-Jones, Lisa. "Dwelling.” Canadian Literature, vol. 197, Summer 2008, pp. 195-96.

Tuan, Yi-Fu. Space and Place: The Perspective of Experience. U of Minnesota P, 1977. 
Tuan, Yi-Fu, and G. H. Schoff. Two Essays on a Sense of Place. Wisconsin Humanities Committee, 1988. Tuana, Nancy. "Viscous Porosity: Witnessing Katrina." Material Feminisms, edited by Stacy Alaimo and Susan Hekman, Indiana UP, 2008, pp. 188-213.

\section{NIEPRZEBRANA UBOGOŚĆ PRZESTRZENI \\ W BROKEN VESSEL HARREGO THURSTONA}

Streszczenie

W styczniu i lutym 2000 roku kanadyjski poeta-naturalista Harry Thurston (ur. 1950) spędził 35 dni na Saharze, towarzysząc grupie archeologów badających Oazę Dachla. Skonfrontowany z bezmiarem terytorium jednocześnie obcego i znajomego, postanowił odpowiedzieć na doświadczenie życia na pustyni za pomocą serii krótkich wierszy, które pisał każdego dnia pobytu na Saharze. Owocem tego duchowego doświadczenia jest tom Broken Vessel (2007), w którym autor próbuje oddać tajemnicę pustyni - przestrzeni, która fascynuje ludzką wyobraźnię od stulecia. Odwołując się do rozróżnienia przestrzeń-miejsce (Tuan), koncepcji tętniącej materii (Bennett), oraz ekokrytycznej idei, w myśl której ekopoezja może być postrzegana jako tworzenie miejsca, artykuł omawia spostrzeżenia Thurstona na temat świata bardziej-niż-ludzkiego, którego przykładem jest pustynia.

Słowa kluczowe: kanadyjska poezja; Harry Thurston; ekopoezja; transmaterialność; bardziej-niż-ludzki; przestrzeń; miejsce; pustynia. 